\title{
The Role of Free Radicals and Antioxidant in Abortion
}

\author{
Aloysius Suryawan ${ }^{1}$, Theresia Monica Rahardjo ${ }^{2, *}$ \\ 'Obstetric and Gynecology Department, Faculty of Medicine, Maranatha Christian University, Jl. Prof. Drg. Suria Sumantri No.65, Bandung, Indonesia \\ ${ }^{2}$ Anesthesia and Intensive Care Department, Faculty of Medicine, Maranatha Christian University, Jl. Prof. Drg. Suria Sumantri No.65, Bandung, Indonesia \\ *Corresponding author. E-mail: theresia_rahardjo@hotmail.com
}

\section{Abstract}

B ACKGROUND: Free radicals and antioxidant exist in balance under normal condition. In prooxidant condition, excessive free radicals can initiate a state of oxidative stress (OS) followed by capillary endothelial cell damage, a process involved in the pathophysiology of abortion.

CONTENT: Abortion is a common complication of pregnancy and occurs in $25 \%$ of women. Many factors can cause abortion including fetal factor, implantation process and hormonal status. Combination those factors with OS influence the entire reproductive life of a woman. Antioxidant can neutralize free radicals and used to reduce OS especially in recurrent abortion.

SUMMARY: Antioxidant therapy is a very interesting field in abortion especially used as prevention approach mainly caused by the high cost of infertility treatment methods.

KEYWORDS: free radical, antioxidant, abortion

Indones Biomed J. 2013; 5(1): 25-30

\begin{abstract}
Abstrak

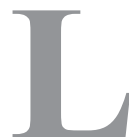

ATAR BELAKANG: Radikal bebas dan antioksidan berada dalam keseimbangan pada kondisi normal. Pada kondisi prooksidan, radikal bebas yang berlebihan dapat menyebabkan stres oksidatif yang diikuti dengan kerusakan sel kapiler endotel, suatu proses yang terlibat di dalam patofisiologi abortus.
\end{abstract}

ISI: Abortus merupakan komplikasi tersering dari kehamilan dan terjadi pada $25 \%$ wanita. Banyak faktor yang dapat menyebabkan abortus seperti faktor fetal, proses implantasi dan status hormonal. Kombinasi faktorfaktor tersebut dengan stress oksidatif akan mempengaruhi seluruh kehidupan reproduksi wanita. Antioksidan dapat menetralisasi radikal bebas dan dapat digunakan untuk menurunkan stress oksidatif pada abortus berulang.

RINGKASAN: Terapi antioksidan merupakan hal yang menarik pada abortus terutama sebagai pencegahan karena tingginya biaya dari metode terapi infertilitas.

KATA KUNCI: radikal bebas, antioksidan, aborsi

\section{Introduction}

Aerobic metabolism is related with the generation of prooxidant molecules called free radicals or reactive oxygen species (ROS) that consist of hydroxyl radicals, superoxide anion, hydrogen peroxide, and nitric oxide (NO). The body has an antioxidant system as a protection against excessive ROS production. Under normal condition, antioxidant acts to oppose ROS production, scavenge existing free radicals, and promote the repair of ROS-induced damage to cell structures.(1)
Antioxidant divided into two groups, first is nonenzymatic antioxidants include vitamin $\mathrm{C}$, vitamin $\mathrm{E}$, selenium, zinc, beta carotene, carotene, taurine, hypotaurine, cysteamine and gluthathione, and second is enzymatic antioxidants include superoxide dismutase (SOD), catalase, glutathione peroxidase (GSH-Px), glutaredoxin and glutathione reductase. The degree of antioxidant defense present is often expressed as total antioxidant capacity (TAC). When the balance between ROS and protection mechanism shifted towards prooxidant, it will produce an excessive ROS, and a state of oxidative stress (OS) is initiated. This condition followed by lipid peroxidation and 
capillary endothelial cell damage, a process involved in the pathophysiology of abortion. Free radical also can influence reproduction function through their interaction with oocytes, sperm, and embryos in their microenvironments, like follicular fluid, hydrosaphingeal fluid, and peritoneal fluid.(1-3)

The review will focus on how free radical and antioxidant influences the pathophysiology of abortion, especially recurrent abortion. In this review, OS is highlighted because it has increasingly important influence in conditions such abortions and other reproduction abnormalities.

\section{Clinical Aspects of Abortion}

Abortion is the spontaneous loss of pregnancy before 20 weeks of gestation. Abortion is a common complication of pregnancy, $25 \%$ of women have experienced abortion. Fifty percent of all the conceptions would be lost, most occurred before the mother realized her pregnancy and only $13.8 \%$ to $22 \%$ of women recognized it. Almost all of the abortion is spontaneous, only $1 \%$ recurrent pregnancy loss occurs because of risk factors in the parents. $(4,5)$

The incidence of abortion varies from $1.5-22 \%$. The incidence of abortion in general is $4-10 \%$ of all pregnancies, while the incidence of abortion imminence varies between $2.5-7.5 \%$. The incidence of abortion in primigravidae is $5-4 \%$ in women who had never pregnant but in women who have experienced abortion are $20 \%$ and increases to $24 \%$ if women had experienced abortion more than once. Other studies find the risk of abortion entirely was $11 \%$, rising to $16 \%$ if it had two previous abortions, as much as $25 \%$ if three times and after four times become $45 \%$. More than $10 \%$ of maternal deaths due to abortion, whereas in developing countries this value is higher at $15-24 \%$, primarily due to bleeding. In Indonesia the incidence of abortion varies between $2.5-4.5 \%$. The percentage of maternal deaths due to abortion ranged from $0.1-1.5 \% .(4,5)$

\section{Cause of Abortion}

\section{Fetal factor and the abnormal development of zygote}

Common morphological finding in early spontaneous abortion is a zygote developmental disorder, followed by embryo and placenta abnormalities. An analysis study of 1,000 cases of spontaneous abortion by Hertig dan Sheldon showed that pathological ovum produces degenerated or none embryo at all. Poland et al. found morphological disorganization of growth at $40 \%$ spontaneous abortion before 20 weeks of gestation. Approximately 50 to $60 \%$ of early spontaneous abortion is accompanied by chromosomal abnormalities in the embryo.(4-6)

\section{Factors affecting the implantation of the embryo into} the endometrium

In early pregnancy, trophoblast implantation is important in determining the success of pregnancy. Trophoblast cells must penetrate the lining of the endometrium and capillary endothelial of blood vessels made of lipids, in this case the phospholipids, and cholesterol sphingolipid.(4-6)

Matrix metalloproteinases (MMP), especially MMP9 , is required in the process of endometrium and basal membrane destruction for embryo implantation. The basal membrane structures are mostly made from collagen and very susceptible to MMP-tissue inhibitors of metalloproteinases (TIMPs) balance mechanism. MMP are zinc-containing enzymes and MMP-9 is a proteinase. This enzyme plays a key role in the implantation process by extracellular matrix degradation through oxidation processes. $(6,7)$

\section{Hormonal Factor}

Hormone deficiency cause implantation failure at an early stage, and is one of the abortion causes. The balance between progesterone, inhibin, activin and human chorionic gonadotropin (hCG) is necessary for pregnancy survival. The studies showed that there is a relationship between decreased progesterone and inhibin levels with abortion.

Progesterone Receptor (PR). Progesterone levels describe the function of the corpus luteum. Abnormal pregnancy has lower progesterone level compared than normal pregnancy. If this is due to low levels of maternal inability to produce a functional corpus luteum, then progesterone supplementation may improve pregnancy outcomes. Contrary to this, supplementation will not help if low progesterone levels due to pregnancy failure. A meta-analysis study showed no benefit of progesterone to maintain the early pregnancy. Progesterone is an important regulator of female reproductive function include uterus, ovary, breast, and brain, and also plays an important role in non-reproductive tissues such as the cardiovascular system, bone and central nervous system, so it can be seen that this hormone has a broad function in normal female physiology. Progesterone has effect through the nuclear $\mathrm{PR}$, which interacts with the transcription co-regulator then moves into the nucleus and regulate gene expression. $\mathrm{PR}$ is a member of a large family of nuclear transcription regulator that is ligand activated, with the characteristics of the specific domain and conserved functions with different 
degrees among species and family members. PR consists of the central DNA binding domain (DBD) and a carboxyl terminal ligand binding domain (LBD). PR also contains multiple elements of activation (AF) and inhibitory (IF) that can enhance and suppress the transcriptional activation of PR through the interaction with co-regulator transcription region. PR newly transcribed cytoplasmic protein complexes are in inactive multi chaperone protein competent to bind the ligand. Binding between progestin with PR causes a conformational change resulting in dissociation of PR chaperones, dimerization, binding to the progestin response elements in the promoter of target genes and specific coactivator retrieval and general transcription factors, which ultimately lead to modulation of transcription of these genes. In humans, the effects of progesterone are mediated by two different forms of PR transcription form resulted from a single gene by transcription initiation from two different promoters, which produce two protein isoforms, PRA and PRB. PRA and PRB are identical, except that the PRA has 164 amino acids at the N-terminus, two proteins shorter than PRB. In mice, PRB is required for the formation of the normal mammary gland, while the PRA is critical for the formation of the uterus and reproductive function. $(6,8)$

Inhibin. Inhibin is a non steroidal glycoprotein with important role in reproductive physiology and divided into inhibin A and B. Inhibin A is a major bioactive inhibin in the circulation and is found in early pregnancy. Circulating inhibin A are involved in the process of implantation and early pregnancy growth. Inhibin also serves as a marker of fetal viability. In women who are not pregnant, inhibin secreted and synthesized by the follicle graaf and corpus luteum. Inhibin also involved in fetomaternal communication controls needed to maintain a pregnancy. Human placenta, decidua and fetal membranes are places of major production and secretion of inhibin $\mathrm{A}$ and $\mathrm{B}$ in maternal serum, amniotic fluid and umbilical cord blood. The corpus luteum is the main place that continued produce inhibin A during pregnancy. In early pregnancy, the mRNA for the inhibin $\alpha, \beta A$ and $\beta B$ are found in the corpus luteum. Inhibin also synthesized and secreted by the growing human placenta. Both $\alpha$ and $\beta A$ subunit mRNA is localized in the human placenta and is the ultimate expression of cyntitiothrofoblast. Inhibin A circulation increased progressively in early pregnancy, which decreased as the 12 weeks pregnancy, followed by an increase in concentration since the age of mid-pregnancy. Low levels of inhibin A in abortion showed its role in the successful of implantation and development of pregnancy. Declining levels of inhibin activates immunological pathway and the extracellular matrix through activin. Immunological pathway activation characterized by increased Thelper cell type 1 (Th1) activity that will produce IFN $\gamma$ whereas activation of extracellular matrix characterized by the release of MMP2 and MMP9. All of these substances will cause damage to the cell membrane in the lining of the endometrium and blood flow changes in decidual spiralis artery that precede the onset of abortion. $(6,9)$

\section{Free Radical}

ROS can modulate cellular functions, and OS can impair the intracellular milieu, resulting in diseased cells or endangered cell survival. Reproductive cells and tissues remain stable when free radical production and the scavenging antioxidants remain in balance. The role of ROS in various diseases of the female reproductive tract has been investigated. ROS can affect a variety of physiological functions in the reproductive tract, and excessive levels can result in precipitous pathologies affecting female reproduction. The oxidant status can influence early embryo development by modifying the key transcription factors, hence modifying gene expression. Abnormality of this process can result in abortion and other reproductive disorders.(10-12)

OS arises from an imbalance between prooxidant molecules generated from aerobic metabolism and protective antioxidants. OS influences the entire reproductive lifespan of a woman. ROS may act as key signaling molecules in physiological processes but at excess, uncontrolled levels they may also mediate pathological processes including abortion. There is a body of literature providing clinical evidence that substantiates the link between OS and recurrent abortion.(1,10-12)

ROS is mainly produced through oxidative phosphorylase, nicotinamide adenine dinucleotide phosphate-oxidase (NADPH) oxidase and xanthin oxidation in the form of superoxide $\left(\mathrm{O}_{2}^{-}\right)$, hydroxyl ion $\left(\mathrm{OH}^{-}\right)$and hydrogen peroxide $\left(\mathrm{H}_{2} \mathrm{O}_{2}\right)$. At 12 weeks gestation when placental oxygen levels increased, an increase in oxygen metabolism through oxidative phosphorylase derived from embryos and produce adenosine triphosphate (ATP) for growth. This reaction is catalyzed by SOD, and produces a number of toxic intermediate, which should be detoxified through the catalase enzyme and GSH-Px mechanism to prevent further damage of the surrounding tissue. Filler and Lew found that oxidase activity in the embryo also increased, especially NADPH oxidase and xanthin oxidase. Superoxide production also increased due to the activity of cells trophoblast.(10-12) 
Role of Free Radicals in Endothelial Dysfunction

Maladaptive change in qualitative or quantitative endothelial function can cause local changes include changes in endothelial anti haemostatic properties, regulation of vascular tonus and permeability of plasma lipoproteins, hyper adhesion of leukocytes and increased production of cytokines and growth factors. These changes are called endothelial dysfunction. Term endothelial activation is specific to one sub cell endothelial dysfunction that was characterized by changes in endothelial function under the influence of some antigenic stimuli resulted to new antigenic and function which is influenced by interaction with leukocytes. Endothelial dysfunction is not only a marker of vascular disease, but also plays an important role in disease initiation and progressivity. Endothelial dysfunction is generally defined as a decrease in the synthesis, release and or activity of endothelium derived NO. Decline of NO bioactivity could lead to endothelial cell activation.(1-3,1012)

In normal conditions, endothelial cells are able to prevent the entry of lipoproteins and monocytes into the artery wall, keeping rhythm and prevent vascular coagulation and thrombosis. Endothelial function is very sensitive to various forms of stress, such as hemodynamic stress, OS and the expression of inflammatory cytokines as well as cholesterol. Endothelial dysfunction is associated with increased permeability, increased adhesion and monocyte infiltration, increased secretion of vasoactive and inflammatory molecules, and increase adhesion and aggregation of platelets, rising pro coagulant and fibrinolysis disorder. Early stage sterogenesis process is fast uptake of inflammatory monocytes at endothelial injury location by an increase in Vascular cell adhesion molecule-1 (VCAM1) and E-selectin.(10-12)

Endothelial dysfunction is more accurately described as endothelial activation. Endothelial activation shifts the existence of endothelial phenotype that is "silent" to "active" and is a condition involving the immune response. Fundamental change involved in this process is the shift of NO-mediated suppression signal to activated redox signal. As explained previously, superoxide reductase (SOR) reacts with SOD and form $\mathrm{H}_{2} \mathrm{O}_{2}$, which is like $\mathrm{NO}$, can diffused quickly into the cell and interact with cysteine groups in proteins to function undisturbed. However, because many chemical factors involved, this has consequences for different purposes, such as phosphorylation of transcription factors, induction core chromatin remodeling and gene transcription, and protease activation. ROS in chronic production can exceed non enzymatic and enzymatic cellular antioxidant capacity, and cause abnormalities of vascular endothelium through activation of the direct.(1013)

\section{Role of Free Radicals in Pregnancy and Abortion}

The increase in oxygen concentration seen during normal early pregnancy makes the body more vulnerable to ROS formation, particularly within the mitochondria where electron leakage from the enzymes of the respiratory chain occurs. This increase in oxygen concentration may also lead to acute stress in the syncytiotrophoblast, with loss of function and extensive degeneration. The syncytiotrophoblast is susceptible to OS because of its location on the villous surface, which makes this tissue first to experience the increase in intervillous $\mathrm{PO}_{2}$. The syncytiotrophoblast also have much lower concentrations of the antioxidant enzymes than other villous tissues during early gestation.(10-15)

The relation between recurrent abortion and OS is not only contributed by the increase in ROS generation seen in early pregnancy but also associated to increased levels of antioxidants needed to neutralize and scavenge excessive ROS present in women with habitual abortion. Wang et al. has reported that levels of plasma vitamin $\mathrm{E}$ and lipid peroxides are increased in pregnant women compared to non-pregnant controls. Lipid peroxidation is an oxidative process that normally occurs at low levels, and antioxidant function has the ability to control the amount of OS it induces. However, when there is a deterioration of the antioxidants' capacity to neutralize ROS, peroxidative activity occurs at the expense of polyunsaturated fatty acids. Simsek et al. evaluated the outcome of deficient antioxidant defense in women with habitual abortion and demonstrated elevated lipoperoxides and significantly decreased vitamin A, E, and beta carotene in this population compared with the control group. This finding confirmed that OS may be involved in the pathogenesis of recurrent abortion.(10-15) Sane et al. found that women with induced or spontaneous abortions showed a maximum rise in serum lipid peroxidase levels immediately before the onset of abortion and significantly depressed levels of serum lipid peroxidase after the abortion was complete. Jenkins et al. studied changes in antioxidant levels by measuring SOD levels, which measure the amount of oxygen ion scavenger that may result in increased ROS production. This study found that SOD levels were significantly lower in women with miscarriage than in healthy pregnant women.(10-15) 


\section{Role of Antioxidants in Pregnancy and Abortion}

The glutathione and glutathione transferase family of enzymes has been studied in patients with recurrent abortion. The GSH-Px reductase antioxidant system is an ROS scavenger, preventing lipid peroxidation in cells and maintaining intracellular homeostasis and redox balance. Studies have shown glutathione concentration and activity to be significantly higher in women with recurrent abortion compared with the glutathione concentration seen in women with normal pregnancies or in healthy, non-pregnant woman. Red blood cell GSH-Px activity was not seen to differ between pregnant women and the control group, but were seen to be significantly deficient in women that had a miscarriage.(13-15)

The bioavailability of selenium is directly related to the activity of the GSH-Px system. GSH-Px catalyzes the reduction of hydrogen peroxide and hydroxyperoxides, acting as a free radical scavenger and preventing the lipid peroxidation of cell membranes. Because GSH-Px is an enzyme that is essential in cells to neutralize the effects of free radicals, selenium concentrations may decrease in those patients at risk of recurrent abortion because selenium is incorporated into the active site of GSH-Px. Al-Kunani et al. reported significantly lower concentrations of selenium in the hair samples of women with recurrent abortion compared with controls. Although this study failed to confirm a difference in the overall blood plasma selenium concentrations in women who had a miscarriage compared with those with viable pregnancies, selenium levels were found to be significantly higher in non-pregnant women, confirming that pregnancy in general is accompanied by a state of increased OS. $(16,17)$

Given some evidences of OS in the pathogenesis of recurrent abortion, many studies have focused on the role of antioxidant supplementation in women affected by recurrent abortion. Poor dietary intake of vitamins has been associated with an increased risk of abortion. For instance, there are a variety of nonenzymatic antioxidants, including vitamins $\mathrm{C}$, E, and $\mathrm{A}$, lycopenes, selenium compounds, lipoic acid, and ubiquinones that have the ability to scavenge ROS and ultimately prevent OS and cellular damage. An observational study demonstrated an association between the risk of spontaneous early abortion and intake of green vegetables, fruit, and dairy products. Some evidence suggests that reduced intake of micronutrients during pregnancy exposes women to nutritional deficiencies and may affect fetal growth. Thus, adequate maternal nutrition, particularly vitamin intake, may be an important factor in preventing abortion. Although the lacking of evidence in regards to exactly what vitamin combinations, type, and amount are optimal for a pregnant woman, the use of any vitamin supplements in pregnancy needs to be carefully monitored and evaluated. Vitamin $\mathrm{C}$ and $\mathrm{E}$ are two popular vitamins that may have a potential role in alleviating the effects of free radicals in women with abortion. Primary function of vitamin $\mathrm{E}$ is to protect against OS-related damage and thereby serve as an antioxidant. In a normal pregnancy, vitamin E level naturally increases, while in an abnormal pregnancy, vitamin E concentrations are lower. Moreover, vitamin $\mathrm{C}$ levels increase physiologically during pregnancy. These occurrences suggest that perhaps vitamins $\mathrm{C}$ and $\mathrm{E}$ may play a role in compensating for the oxidative burst during early pregnancy, reducing the risk of pregnancy loss. However, it is necessary to perform an accurate assessment of the appropriate type and dosage of vitamins that can be tolerated without causing deleterious side-effects to the mother and baby. $(18,19)$

Study by Quere et al. evaluating the effect of vitamin supplementation on pregnancy outcome in 25 women with recurrent early pregnancy loss and hyperhomocysteinemia in the absence of any folate supplementation during pregnancy. This study involved hyperhomocysteinemic patients. Folic acid supplements are believed to reduce a woman's risk for having a baby with a neural-tube defect. The potential for folic acid to prevent elevated homocysteine levels and OSinduced abortion has been the focus of many investigations. Szymanski et al. found that women receiving folic acid supplements had better quality oocytes and a higher degree of mature oocytes compared with those who did not receive folic acid supplementation. However, the results of a study by Gindler et al. failed to confirm that the consumption of folic acid decrease a woman's risk for miscarriage. Thus, the role of folic acid supplementation to prevent recurrent pregnancy loss is inconclusive and requires further analysis. (18-21)

\section{Conclusion}

Free radicals and OS have important roles in modulating many physiological functions in reproduction, in this case is recurrent abortion and others pregnancy abnormalities. The evaluation of in vivo OS is difficult. The minimum well tolerated concentration, and the physiological levels of ROS in the reproductive tract, need to be defined. Study with specific biomarkers may help identify the relationship between free radicals, recurrent abortion and effect of antioxidant supplementation. Reports of antioxidant therapy 
in recurrent abortion are few and antioxidant therapies have not resulted in modification of outcomes. These fields are interesting areas to pursue, especially using preventative approach mainly caused by the high cost of such infertility treatments.

\section{References}

1. Sekhon LH, Gupta S, Kim Y, Agarwal A. Female Infertility and Antioxidants. Curr Wom Health Rev. 2010; 6: 84-95.

2. Agarwal A, Gupta S. Sikka S. The role of free radicals and antioxidants in reproduction. Curr Opin Obstet Gynecol. 2006;18: 325-32.

3. Agarwal A, Aponte-Mellado A, Premkumar BJ, Sharman A, Gupta S. The Effects of Oxidative Stress on Female Reproduction: A Review. Endocrinol. 2012; 10: 1-31.

4. Hill JA. Recurrent Pregnancy Loss. In: Creasy RK, Resnik R, editor. Maternal-Fetal Medicine. 5th ed. Philadelphia: Saunders; 2004. p.579-602.

5. Wijayanegara H. Aspek Klinis Abortus. In: Handono B, Firman FW, Mose JC, editors. Abortus Berulang. Bandung: Refika Aditmana; 2009. p.1-13.

6. Toth B, Jeschke U, Rogenhofer N, Scholz C, Wurfel W, Thaler CJ, et al. Recurrent miscarriage: current concepts in diagnosis and treatment. J Reprod Immunol. 2010; 85: 25-32.

7. Staun-Ram E, Goldman S, Gabarin D, Shalev E. Expression and importance of matrix metalloproteinase 2 and 9 (MMP-2 and MMP9) in human trophoblast invasion. Reprod Biol Endocrinol. 2004; 2: 59.

8. Scarpin KM, Graham JD, Mote PA, Clarke CL. Progesterone action in human tissues: regulation by progesterone receptor (PR) isoform expression, nuclear positioning and coregulator expression. Nucl Recept Signal 2009; 7: e009.

9. Muttukrishna S, Bearfield C, John J, Jaunioux E. Inhibin, Activin, Follistatin, Activin receptors and B-glycan Gene Expression in the Villous Tissue of Misscariage Patient. Mol Hum Reprod. 2004; 11: 793-8.

10. Abdul-Barry J, Al-Rubai SA, Qasim QA. Study of Oxidant-Antioxidant Status in Recurrent Spontaneous Abortion. TQMJ. 2011; 5:35-46.

11. Mistry HD, Williams PJ. The Importance of Antioxidant Micronutrients in Pregnancy. Oxid Med Cell Longev. 2011; 2011: 841749.

12. Poston L, Igosheva N, Mistry HD, Seed PT, Shennan AH, Rana S, et al. Role of oxidative stress and antioxidant supplementation in pregnancy disorders. Am J Clin Nutr. 2011; 94(6 Suppl): 1980S-5S.

13. Lim KJ, Odukoya OA, Li TC, Cooke ID. Cytokines and immunoendocrine factors in recurrent miscarriage. Human Reprod Update. 1996; 2: 469-81.

14. Stankov OJ, Duric J, Dobutovic B, Isenovich ER. Determination of Total Antioxidant Status (TAS) as a Biochemical Parameter in Control of Workers' Health. Arsh Biol Sci. 2009; 61: 375-82.

15. Gupta S, Banerjee J, Agarwal A. The Impact of Reactive Oxygen Species on Early Human Embryos: A Systematic Review of the Literature. Embryo Talk. 2006; 1: 87-98.

16. Al-Kunani AS, Knight R, Haswell SJ, Thompson W, Lindow SW. The selenium status of women with a history of recurrent miscarriage. BJOG. 2001; 108: 1094-7.

17. Padayatty SJ, Katz A, Wang Y, Eck P, Kwon O, Lee JH, et al. Vitamin $\mathrm{C}$ as an Antioxidant: Evaluation of Its Role in Disease Prevention. J Am Coll Nutr. 2003; 22: 18-35.

18. Han M, Pendem S, Teh SL, Sukumaran DK, Wu F, Wilson JX. Ascorbate protects endothelial barrier function during septic insult: Role of protein phosphatase type 2A. Free Radic Biol Med. 2010;
48: 128-35.

19. Lonn E, Bosch J, Yusuf S, Sheridan P, Pogue J, Arnold JM, et al. Effects of Long-term Vitamin E Supplementation on Cardiovascular Events and Cancer: a rondomized clinial trial. JAMA. 2005; 293:1338-47.

20. Reidling KC, Subramanian VS, Dahhan T, Sadat M, Said HM. Mechanisms and Regulation of Vitamin C Uptake: Studies of the hSVCT Systems inHuman Liver Epithelial Cells. Am J Physiol Gastrointest Liver Physiol. 2008; 295: G1217-27.

21. Kammerer C, Getoff N. Synergistic Effect of Dehydroascorbic Acid and Mixtures with Vitamin E and B-Carotene on Mitomycin C Efficiency Under Irradiation In Vitro. In Vivo. 2004; 18: 795-8. 